\title{
Development of a novel plaque reduction neutralisation test for hantavirus infection
}

\author{
Michelly de Pádua, William Marciel de Souza, Flávio Lauretti, Luiz Tadeu Moraes Figueiredo/+
}

${ }^{1}$ Universidade de São Paulo, Faculdade de Medicina de Riberão Preto, Centro de Pesquisa em Virologia, Ribeirão Preto, SP, Brasil

In the Americas, hantaviruses cause severe cardiopulmonary syndrome (HCPS) with a high fatality rate. Hantavirus infection is commonly diagnosed using serologic techniques and reverse transcription-polymerase chain reaction. This paper presents a novel plaque reduction neutralisation test (PRNT) for detecting antibodies to Brazilian hantavirus. Using PRNT, plaque detection was enhanced by adding $0.6 \%$ of dimethyl sulfoxide into the overlay culture medium of the infected cells. This procedure facilitated clear visualisation of small plaques under the microscope and provided for easy and accurate plaque counting. The sera from 37 HCPS patients from the city of Ribeirão Preto, Brazil was evaluated for the Rio Mamoré virus (RIOMV) using PRNT. Six samples exhibited neutralising antibodies; these antibodies exhibited a low titre. The low level of seropositive samples may be due to fewer cross-reactions between two different hantavirus species; the patients were likely infected by Araraquara virus ( $a$ virus that has not been isolated) and RIOMV was used for the test. This assay offers a new approach to evaluating and measuring neutralising antibodies produced during hantavirus infections and it can be adapted to other hantaviruses, including viruses that will be isolated in the future.

Key words: hantavirus - plaque reduction neutralisation test - cross-reaction in neutralisation test - Rio Mamoré virus

Hantavirus is a genus of the family Bunyaviridae; the viruses in this genus are enveloped negative-sense RNA viruses. The viral genome contains three segments, including a large segment (L) that encodes the viral RNA polymerase, a medium segment (M) that encodes two envelope glycoproteins ( $\mathrm{Gn}$ and $\mathrm{Gc}$ ) and a small segment $(\mathrm{S})$ that encodes the viral nucleocapsid protein $(\mathrm{N})$ as well as a small nonstructural protein that has been described in certain species, such as the Tula, Puumala and Andes viruses (Schmaljohn \& Nichol 2007, Jonsson et al. 2010, Vera-Otarola et al. 2012).

Hantaviruses are transmitted to humans mainly through inhaling aerosolised excreta and secretions of infected rodents or through direct contact with the secretions (Jonsson et al. 2010). Additionally, human-to-human transmission of the Andes hantavirus was reported in Argentina and Chile (Padula et al. 1998, Martinez et al. 2005, Martinez-Valdebenito et al. 2014). Human infections by hantaviruses can produce fever that can be differentiated into two types of disease: haemorrhagic fever with renal syndrome, which is more widely described in Europe and Asia and cardiopulmonary syndrome (HCPS), which is typically restricted to the Americas (Clement et al. 2014, Figueiredo et al. 2014).

South America includes four hantavirus species (the Andes, Rio Mamoré, Laguna Negra and Cano Delgadito

doi: 10.1590/0074-02760150102

Financial support: FAPESP (08/50617-6; scholarships 11/16866-1,

11/05067-0, 12/24150-9), CNPq (301677/2013-1)

+ Corresponding author: 1tmfigue@fmrp.usp.br

Received 15 March 2015

Accepted 3 June 2015 viruses) with more than 30 variants responsible for approximately $4,000 \mathrm{HCPS}$ cases. This severe disease produces rapid onset of respiratory failure and cardiogenic shock. Hantaviruses are an important emerging problem for public health in South America. Urban areas, agriculture and cattle-raising have generated invading ecosystems containing most of the Sigmodontinae rodent species that act as hantavirus reservoirs (Figueiredo et al. 2014, Souza \& Figueiredo 2014). As a result, Brazil has the highest number of HCPS cases in the Americas at approximately 2,000. Nonetheless, asymptomatic or oligosymptomatic hantavirus infections may occur in a higher number than in HCPS cases. Additionally, many HCPS cases may not be correctly diagnosed or may remain undiagnosed (Figueiredo et al. 2014).

In Brazil, laboratories diagnose hantavirus infection using serology (ELISA) and molecular methods [polymerase chain reaction preceded by reverse transcription (RT-PCR)] (Moreli et al. 2004, Figueiredo et al. 2008, 2009a, Machado et al. 2013). Additionally, other serological methods can be used for diagnosis, such as Western blot and immunofluorescence (Figueiredo et al. 2014). Neutralisation assays, which are the most specific serologic tests, are not commonly used for a routine hantavirus infection diagnosis because are the tests are laborious and demand biosafety level (BSL)-3 laboratories to handle the virus. However, neutralisation tests are useful for identifying the infecting hantavirus and are included in the four criteria of the International Committee on Taxonomy of Viruses (ICTV) to delineate and characterise a new species (Jonsson et al. 2010, Plyusnin et al. 2012). Currently, a range of neutralisation assays are available for hantaviruses, such as a peroxidaseanti-peroxidase system, chemiluminescent substrates, quantitative RT-PCR and microplaques (Tanishita et al. 1984, Niklasson et al. 1991, Heider et al. 2001, Maes et 
al. 2009). However, the assays are limited to the hantaviruses from Asia, Europe and in the Americas, which are restricted to the hantaviruses Andes, Sin Nombre and Choclo (Bharadwaj et al. 2000, Valdivieso et al. 2006, Nelson et al. 2010). In Brazil, neutralisation assays are not available for hantaviruses, likely because a local hantavirus has not been isolated. Thus, the aim of the present paper is to evaluate a novel assay for detecting and quantifying neutralising antibodies in patients infected by a hantavirus in Brazil.

\section{SUBJECTS, MATERIALS AND METHODS}

Serum samples, ELISA and RT-PCR - We analysed the samples using a neutralisation test; we used serum samples from 37 patients from the city of Ribeirão Preto, state of São Paulo, Brazil with HCPS previously confirmed through positive IgM or a high IgG titre in ELISAs using a recombinant $\mathrm{N}$ protein from Araraquara virus (ARAQV) as the antigen (Figueiredo et al. 2008, 2009a). Additionally, in 27 of the samples, the ARAQV genome was amplified using RT-PCR (Moreli et al. 2004). An infection by ARAQV was confirmed in these patients through sequencing the amplicons containing 264 nucleotides from the viral S segment.

Virus culture - The Rio Mamoré virus (RIOMV) strain HTN-0007 was kindly provided by Dr Robert E Shope from the University of Texas Medical Branch, at Galveston. The virus was grown in Vero-E6 cells (African green monkey kidney) and maintained in Eagle's minimum essential medium (EMEM) supplemented with $10 \%$ heat-inactivated foetal bovine serum, $50 \mathrm{mg} /$ $\mathrm{mL}$ of gentamicin and $2 \mathrm{mg} / \mathrm{mL}$ of amphotericin B (Vitrocell, Brazil). The cells infected with RIOMV were cultivated for 14 days at $37^{\circ} \mathrm{C}$ with $5 \% \mathrm{CO}_{2}$. Tissue culture medium obtained from flasks containing infected cells was aliquoted as a viral stock and stored at $-70^{\circ} \mathrm{C}$.

Plaque (microplaque) assay - The plaque assays (microplaques) were performed after the Vero-E6 cell colonies were incubated for $48 \mathrm{~h}$ at $2 \times 10^{5}$ cells per well in 24 -well plates. We added $150 \mu \mathrm{L}$ per plate well of decimal serial dilutions $\left(10^{-1}-10^{-8}\right)$ using the RIOMV stock to the Vero-E6 colonies in duplicate. The microplates were allowed to adsorb for $1 \mathrm{~h}$ at $37^{\circ} \mathrm{C}$ with $5 \% \mathrm{CO}_{2}$ and were gently rocked every $15 \mathrm{~min}$. After adsorption, each well was overlaid with $1 \mathrm{~mL}$ of a medium-viscosity medium containing $1.5 \%$ of carboxymethylcellulose sodium (Sigma-Aldrich, Germany) in EMEM supplemented with 1.5\% of foetal calf serum and $0.3-1.5 \%$ of dimethyl sulfoxide (DMSO) (Sigma-Aldrich). The plates were incubated for 13 days at $37^{\circ} \mathrm{C}$ with $5 \% \mathrm{CO}_{2}$. After incubation, the cell monolayers were rinsed and fixed with a $10 \%$ buffered formalin solution for $1 \mathrm{~h}$ at room temperature and under constant agitation. Uninfected cells were fixed and used as negative controls. The plates infected with RIOMV were handled in a BSL-3 laboratory. The fixed cell monolayers were stained using a naphthalene black solution $(0.1 \%$ naphthol blue-black, $6 \%$ glacial acetic acid and $1.36 \%$ sodium acetate) under constant agitation for $1 \mathrm{~h}$.

Finally, the microplaques in the cell monolayers were counted under a microscope. The RIOMV stock titre was calculated as plaque-forming units (PFUs) per millilitre using the following formula: viral titre (PFU/ $\mathrm{mL}$ ) = number of microplaques $\mathrm{x}$ dilution factor/volume of virus or virus-serum-mixture per well.

Plaque (microplaque) reduction neutralisation test - Heat-inactivated serum specimens $\left(56^{\circ} \mathrm{C}\right.$ for $\left.30 \mathrm{~min}\right)$ were diluted two-fold (1:10-1:160) with EMEM and 250 $\mu \mathrm{L}$ of each serum dilution was mixed to the same volume of a solution containing 100 PFU of RIOMV. We also mixed serum from healthy individuals who were negative for hantavirus antibodies with the virus, which was used as a negative control in the assay. Tubes containing the mixtures were incubated for $1 \mathrm{~h}$ at $37^{\circ} \mathrm{C}$ to allow the neutralising antibodies to bind with the virus. Thereafter, $250 \mu \mathrm{L}$ of the virus-serum mixture was added to the wells in duplicate and the plate was incubated for $1 \mathrm{~h}$. Next, the virus-serum mixtures were removed and the wells were rinsed in phosphate-buffered saline (PBS). Two wells containing only culture medium were used as negative controls and two other wells were inoculated with $100 \mathrm{PFU}$ of RIOMV as positive controls. The plates were incubated at $37^{\circ} \mathrm{C}$ with $5 \% \mathrm{CO}_{2}$ and gently rocked every $15 \mathrm{~min}$ for $1 \mathrm{~h}$. Thereafter, each well was overlaid with $1 \mathrm{~mL}$ of the semi-solid overlay medium used for the microplaque assay and the cell monolayers were incubated for 13 days at $37^{\circ} \mathrm{C}$ in a $\mathrm{CO}_{2}$ incubator, as mentioned above. Next, the cell monolayers were stained with naphthalene black, as described above. A neutralising antibody titre was defined as the maximum serum dilution that inhibited $50 \%$ of microplaque formation by RIOMV in the cell monolayer (Yu et al. 2013).

\section{RESULTS}

Virus microplaques were not observed either without using DMSO or using $0.3 \%$ of DMSO in the cell culture medium. Using $0.6 \%$ and $0.8 \%$ of DMSO, the microplaques in the cell monolayer were visible 13 days after infection. Using $1 \%$ DMSO, we observed increased destruction of the cell monolayer and the microplaques became impossible to distinguish. Concentrations of $1.5 \%$ DMSO or higher promoted considerable destruction of the cell monolayer, likely due to a toxic effect. Based on these results, we used $0.6 \%$ as the DMSO concentration in the medium-viscosity overlay medium.

Under the microscope, microplaques with an average size of $328 \mu \mathrm{m}( \pm 94 \mu \mathrm{m})$ and an irregular border were used to determine the RIOMV titre of our stock as $6.6 \times$ $10^{5} \mathrm{PFU} / \mathrm{mL}$ (Figure).

Neutralising antibodies against RIOMV were observed in $16.21 \%(6 / 37)$ of the patient sera. Neutralising antibody titres ranged from 10-80. The titre of the neutralising antibodies could not be correlated with evolution (survival or death) of the patients, as shown in Table. Additionally, the neutralising antibody titres could not be correlated with the titres obtained using IgG-ELISA and the $\mathrm{N}$ recombinant antibody of ARAQV as an antigen. For example, the serum from one fatal HCPS case (patient 9) (Table) exhibited a 6,400 titre in the IgG ELISA, but exhibited only a 40 titre in the neutralisation test.

\section{DISCUSSION}

In cell culture, hantavirus infection typically yields a slow cytopathic effect that also reduces plaque production 

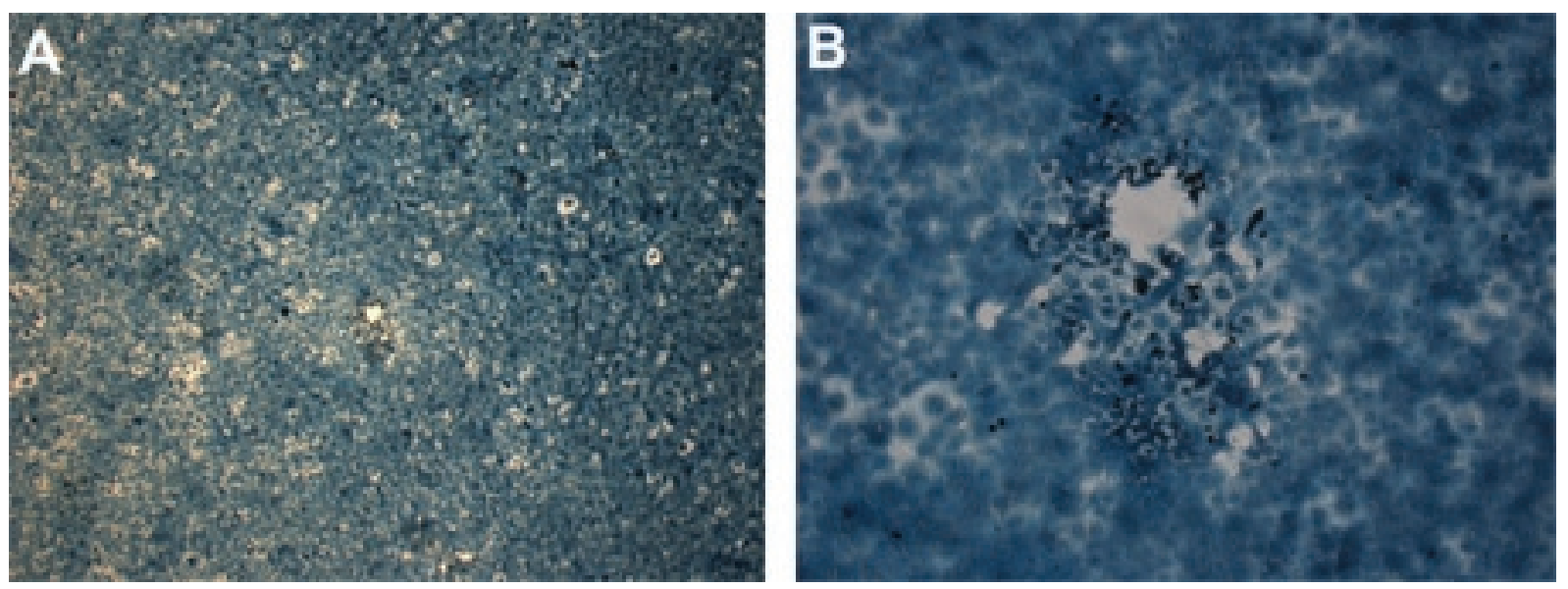

Microplaques formed in Vero-E6 cell infected by Rio Mamoré virus with addition of dimethyl sulfoxide $0.6 \%$ in medium-viscosity overlay medium. Shown in 40X (A) and 1,000X (B).

(Markotic et al. 2003). In the present study, we adapted a treatment for virus-infected cells using DMSO; this treatment has been indicated as capable of increasing the size and number of plaques in virus-infected cell monolayers (Hughes 1993). Therefore, we found that adding $0.6 \%$ of DMSO to the medium-viscosity overlay enhances microplaque formation in Vero-E6 cell cultures infected by hantavirus (RIOMV), which facilitates clear visualisation of these microplaques under the microscope.

It is a known difficulty to adapt wild hantavirus to cell culture. In certain cases, the virus is lost after three or four passages, which occurred using ARAQV in our laboratory (Kallio et al. 2006). Thus, we used RIOMV, which is a virus that is well-adapted to Vero-E6 cell culture for use in the plaque (microplaque) reduction neutralisation test.

RIOMV was first described in Bolivia in 1996 and was associated with the Oligoryzomys microtis rodent (Bharadwaj et al. 1997). RIOMV was also isolated from $O$. microtis in Peru and two strains of the virus were observed in the Brazilian Amazon and infected the same rodent as well as Oligoryzomys sp. RIOMV-producing HCPS has recently been described in Peru (2 cases) and in French Guiana (1 case produced by the variant Maripa virus) (Figueiredo et al. 2014). A human fatal disease involving RIOMV was recently reported in Brazil (Carvalho de Oliveira et al. 2014).

ARAQV was first observed in a fatal HCPS case from the city of Araraquara in 1995. ARAQV is harboured by Necromys lasiurus, which is a rodent that lives in regions of Brazilian Cerrado (a savannah-like ecosystem) (Suzuki et al. 2004). ARAQV is the most virulent hantavirus in Brazil and causes HCPS with an approximately $50 \%$ case-fatality rate in the southeastern region as well as in the central plateau (Figueiredo et al. 2014). Serum samples analysed in the present study were collected from patients that were likely infected by ARAQV.

To detect hantavirus-neutralising antibodies, we developed a test that considers the ability of serum to reduce the number of microplaques by $50 \%$. Other authors have successfully reduced plaques against hantaviruses by $50 \%$ (Yu et al. 2013). Hantavirus-neutralising anti- bodies can be observed earlier than 10 days after infection and are commonly present at the onset of a hantavirus disease (Horling et al. 1992). Using our microplaque reduction neutralisation test for RIOMV, we identified these antibodies in $16.2 \%$ of the tested sera. The low level of positivity in samples that were previously diagnosed through ARAQV genome amplification using RTPCR $(73 \%)$ and by IgG or IgM-ELISAs using ARAQV (all samples) was likely due to ARAQV antibodies crossreacting with RIOMV; this inconsistency was only present in six samples (Figueiredo et al. 2009b).

As previously demonstrated, ARAQV induces a mixed T-helper (Th)1/Th2 strong immune response during the course of HCPS and the magnitude of the Th1 response effector cytokines is correlated with disease severity (Borges et al. 2006). However, protection markers that clearly relate to disease survival are not wellknown. Previous work has shown that a neutralising antibody immune response confers protection from disease severity by the Andes virus in animals (Custer et al. 2003). Previous work has also shown that high neutralising antibody titres correlate with less severe HCPS cases (Bharadwaj et al. 2000). Neutralising antibodies specifically bind to certain extracellular hantavirus protein epitopes and impair infection of its target cells, which also reduces the level of free virus (Borges et al. 2006, Easterbrook \& Klein 2008, Kruger et al. 2011). Thus, the level of hantavirus-neutralising antibodies may suggest HCPS prognoses in addition to discerning the infecting virus. However, we did not observe a correlation between patient prognosis and neutralising antibody titres in the present study and fatal cases showed the same neutralising antibody titre as the survivors. The lower number of studied cases may have influenced our results. Moreover, we could not obtain information on the infecting virus because patients were infected by ARAQV and the virus used in the neutralisation test was RIOMV.

In our study, low neutralising serum titres were observed in all six positive sera (a titre of 80 or less). This result is consistent with previously observed titres in survivors of hantavirus infections with the Andes and 
TABLE

Comparison of neutralising and nonneutralising antibody titres with IgG titre detection of genome by reverse transcription-polymerase chain reaction (RT-PCR) and status of disease

\begin{tabular}{|c|c|c|c|c|c|}
\hline Patient ID & RT-PCR & ELISA & IgG titre & Death & Neutralisation \\
\hline 1 & Positive & $\operatorname{IgG}$ & 12,800 & No & None \\
\hline 2 & Positive & $\mathrm{IgG}$ & 12,800 & No & None \\
\hline 3 & Positive & $\mathrm{IgG}$ & 12,800 & No & None \\
\hline 4 & Positive & $\mathrm{IgG}$ & 6,400 & No & 40 \\
\hline 5 & Positive & $\mathrm{IgG}$ & 12,800 & No & None \\
\hline 6 & Positive & $\mathrm{IgG}$ & 6,400 & No & 20 \\
\hline 7 & Positive & $\mathrm{IgG}$ & 1,600 & No & None \\
\hline 8 & Positive & $\mathrm{IgG}$ & 3,200 & No & None \\
\hline 9 & Positive & $\mathrm{IgG}$ & 12,800 & No & 40 \\
\hline 10 & Positive & $\mathrm{IgG}$ & 12,800 & No & None \\
\hline 11 & None & $\mathrm{IgG} / \operatorname{IgM}$ & 3,200 & No & None \\
\hline 12 & None & $\mathrm{IgG} / \operatorname{IgM}$ & 6,400 & No & None \\
\hline 13 & Positive & $\mathrm{IgG} / \operatorname{IgM}$ & 400 & Yes & None \\
\hline 14 & Positive & $\operatorname{IgG} / \operatorname{IgM}$ & 12,800 & No & None \\
\hline 15 & None & $\operatorname{Ig} G$ & 12,800 & No & 80 \\
\hline 16 & None & $\mathrm{IgG}$ & $1: 400$ & No & None \\
\hline 17 & Positive & $\operatorname{IgG} / \operatorname{IgM}$ & 3,200 & No & None \\
\hline 18 & Positive & $\mathrm{IgG} / \operatorname{IgM}$ & 3,200 & No & None \\
\hline 19 & Positive & $\mathrm{IgG} / \operatorname{IgM}$ & 6,400 & No & None \\
\hline 20 & None & $\mathrm{IgG}$ & 100 & No & None \\
\hline 21 & None & $\mathrm{IgG}$ & 6,400 & No & 40 \\
\hline 22 & None & $\mathrm{IgG} / \operatorname{IgM}$ & 100 & No & None \\
\hline 23 & Positive & $\mathrm{IgG} / \operatorname{IgM}$ & 12,800 & No & None \\
\hline 24 & Positive & $\mathrm{IgG} / \operatorname{IgM}$ & 12,800 & Yes & None \\
\hline 25 & Positive & $\mathrm{IgG} / \operatorname{IgM}$ & 800 & No & None \\
\hline 26 & Positive & $\mathrm{IgG} / \operatorname{IgM}$ & 6,400 & No & None \\
\hline 27 & None & $\mathrm{IgG}$ & 400 & No & None \\
\hline 28 & Positive & $\mathrm{IgG} / \operatorname{IgM}$ & 400 & Yes & None \\
\hline 29 & Positive & $\mathrm{IgG} / \operatorname{IgM}$ & 200 & No & None \\
\hline 30 & Positive & $\mathrm{IgG}$ & 400 & No & None \\
\hline 31 & Positive & $\mathrm{IgG}$ & 400 & Yes & None \\
\hline 32 & Positive & $\mathrm{IgG}$ & 6,400 & Yes & 40 \\
\hline 33 & None & $\operatorname{IgG} / \operatorname{IgM}$ & 1,600 & No & None \\
\hline 34 & Positive & $\mathrm{IgG} / \operatorname{IgM}$ & 6,400 & Yes & None \\
\hline 35 & None & $\mathrm{IgG} / \operatorname{IgM}$ & 800 & No & None \\
\hline 36 & Positive & $\mathrm{IgG} / \operatorname{IgM}$ & 1,600 & No & None \\
\hline 37 & Positive & $\mathrm{IgG}$ & 400 & No & None \\
\hline
\end{tabular}

Sin Nombre viruses, where high neutralising-antibody titres against the hantavirus predominant in each region were observed and titres lower than 100 were observed through cross-reaction neutralisation for other species of hantavirus (Valdivieso et al. 2006). Furthermore, neutralising antibodies compose a small proportion of the antibodies against hantavirus in HCPS patients. Moreover, RIOMV belongs to a different species of ARAQV than the virus that infected our patients.

Herein, we showed the development and evaluation of a microplaque reduction neutralisation test for RIOMV that can detect and quantify hantavirus-neutralising antibodies in patient sera. This assay could be used to diagnose infection, in pathogenesis studies and to analyse antiviral drugs. Additional studies using ARAQV or another genotype adapted to cell culture are necessary to detect neutralising antibodies against hantaviruses that cause HCPS in Brazil and in other South American countries (Figueiredo et al. 2009b, Souza et al. 2011, 2012).

\section{REFERENCES}

Bharadwaj M, Botten J, Torrez-Martinez N, Hjelle B 1997. Rio Mamoré virus: genetic characterization of a newly recognized hantavirus of the pygmy rice rat, Oligoryzomys microtis, from Bolivia. Am J Trop Med Hyg 57: 368-374.

Bharadwaj M, Nofchissey R, Goade D, Koster F, Hjelle B 2000. Humoral immune responses in the hantavirus cardiopulmonary syndrome. J Infect Dis 182: 43-48. 
Borges AA, Campos GM, Moreli ML, Souza RL, Aquino VH, Saggioro FP, Figueiredo LT 2006. Hantavirus cardiopulmonary syndrome: immune response and pathogenesis. Microbes Infect 8: $2324-2330$.

Carvalho de Oliveira R, Cordeiro-Santos M, Guterres A, Fernandes J, de Melo AX, Joao GA, Novais MA, Travassos da Rosa ES, Vasconcelos PF, Vilges de Oliveira S, Claudio de Albuquerque B, Sampaio de Lemos ER 2014. Rio Mamoré virus and hantavirus pulmonary syndrome, Brazil. Emerg Infect Dis 20: 1568-1570.

Clement J, Maes P, Van Ranst M 2014. Hemorrhagic fever with renal syndrome in the new and hantavirus pulmonary syndrome in the Old World: paradi(se)gm lost or regained? Virus Res 187: 55-58.

Custer DM, Thompson E, Schmaljohn CS, Ksiazek TG, Hooper JW 2003. Active and passive vaccination against hantavirus pulmonary syndrome with Andes virus M genome segment-based DNA vaccine. J Virol 77: 9894-9905.

Easterbrook JD, Klein SL 2008. Immunological mechanisms mediating hantavirus persistence in rodent reservoirs. PLoS Pathog 4: e1000172.

Figueiredo LT, Moreli ML, Borges AA, de Figueiredo GG, Badra SJ, Bisordi I, Suzuki A, Capria S, Padula P 2009a. Evaluation of an enzyme-linked immunosorbent assay based on Araraquara virus recombinant nucleocapsid protein. Am J Trop Med Hyg 81: 273-276.

Figueiredo LT, Moreli ML, Borges AA, Figueiredo GG, Souza RL, Aquino VH 2008. Expression of a hantavirus N protein and its efficacy as antigen in immune assays. Braz J Med Biol Res 41: 596-599.

Figueiredo LT, Moreli ML, de-Sousa RL, Borges AA, de-Figueiredo GG, Machado AM, Bisordi I, Nagasse-Sugahara TK, Suzuki A, Pereira LE, de-Souza RP, de-Souza LT, Braconi CT, Harsi CM, de-Andrade-Zanotto PM, Viral Diversity Genetic Network C 2009b. Hantavirus pulmonary syndrome, central plateau, southeastern and southern Brazil. Emerg Infect Dis 15: 561-567.

Figueiredo LT, Souza WM, Ferres M, Enria DA 2014. Hantaviruses and cardiopulmonary syndrome in South America. Virus Res 187: $43-54$

Heider H, Ziaja B, Priemer C, Lundkvist A, Neyts J, Kruger DH, U1rich R 2001. A chemiluminescence detection method of hantaviral antigens in neutralisation assays and inhibitor studies. $J$ Virol Methods 96: 17-23.

Horling J, Lundkvist A, Huggins JW, Niklasson B 1992. Antibodies to Puumala virus in humans determined by neutralization test. $J$ Virol Methods 39: 139-147.

Hughes JH 1993. Physical and chemical methods for enhancing rapid detection of viruses and other agents. Clin Microbiol Rev 6: 150-175.

Jonsson CB, Figueiredo LT, Vapalahti O 2010. A global perspective on hantavirus ecology, epidemiology and disease. Clin Microbiol Rev 23: 412-441.

Kallio ER, Klingström J, Gustafsson E, Manni T, Vaheri A, Henttonen H, Vapalahti O, Lundkvist A 2006. Prolonged survival of Puumala hantavirus outside the host: evidence for indirect transmission via the environment. J Gen Virol 87: 2127-2134.

Kruger DH, Schonrich G, Klempa B 2011. Human pathogenic hantaviruses and prevention of infection. Hum Vaccin 7: 685-693.

Machado AM, de Souza WM, de Padua M, da Silva Rodrigues Machado AR, Figueiredo LT 2013. Development of a one-step SYBR Green I real-time RT-PCR assay for the detection and quantitation of Araraquara and Rio Mamoré hantavirus. Viruses 5: 2272-2281.

Maes P, Keyaerts E, Li S, Nlandu-Masunda V, Clement J, Van Ranst M 2009. Replication reduction neutralization test, a quantitative RT-PCR-based technique for the detection of neutralizing hantavirus antibodies. J Virol Methods 159: 295-299.
Markotic A, Hensley L, Geisbert T, Spik K, Schmaljohn C 2003. Hantaviruses induce cytopathic effects and apoptosis in continuous human embryonic kidney cells. J Gen Virol 84: 2197-2202.

Martinez VP, Bellomo C, San Juan J, Pinna D, Forlenza R, Elder M, Padula PJ 2005. Person-to-person transmission of Andes virus. Emerg Infect Dis 11: 1848-1853.

Martinez-Valdebenito C, Calvo M, Vial C, Mansilla R, Marco C, Palma RE, Vial PA, Valdivieso F, Mertz G, Ferres M 2014. Person-toperson household and nosocomial transmission of Andes hantavirus, Southern Chile, 2011. Emerg Infect Dis 20: 1629-1636.

Moreli ML, de Sousa RLM, Figueiredo LTM 2004. Detection of Brazilian hantavirus by reverse transcription polymerase chain reaction amplification of $\mathrm{N}$ gene in patients with hantavirus cardiopulmonary syndrome. Mem Inst Oswaldo Cruz 99: 633-638.

Nelson R, Canate R, Pascale JM, Dragoo JW, Armien B, Armien AG, Koster F 2010. Confirmation of Choclo virus as the cause of hantavirus cardiopulmonary syndrome and high serum antibody prevalence in Panama. J Med Virol 82: 1586-1593.

Niklasson B, Jonsson M, Lundkvist A, Horling J, Tkachenko E 1991. Comparison of European isolates of viruses causing hemorrhagic fever with renal syndrome by a neutralization test. Am J Trop Med Hyg 45: 660-665.

Padula PJ, Edelstein A, Miguel SD, Lopez NM, Rossi CM, Rabinovich RD 1998. Hantavirus pulmonary syndrome outbreak in Argentina: molecular evidence for person-to-person transmission of Andes virus. Virology 241: 323-330.

Plyusnin AB, Elliott RM, Goldbach R, Kormelink R, Lundkvist Å, Schmaljohn CS, Tesh RB 2012. Bunyaviridae. In Virus taxonomy: classification and nomenclature of viruses, Elsevier, San Diego, p. 693-709.

Schmaljohn CS, Nichol ST 2007. Bunyaviridae. In DM Knipe, PM Hoeley, DE Griffin, RA Lamb, MA Martin, B Roizman, SE Straus, Fields virology, Lippincott Williams \& Wilkins, Philadelphia, p. 1741-1789.

Souza WM, Figueiredo LT 2014. Analysis of the nucleocapsid gene brings new insights to the classification of Sigmodontinae-borne hantaviruses. Arch Virol 159: 2475-2477.

Souza WM, Machado AM, Disner GR, Boff E, Machado AR, Padua M, Figueiredo LT, Miranda GB 2012. Antibody levels to hantavirus in inhabitants of western Santa Catarina state, Brazil. Rev Inst Med Trop Sao Paulo 54: 193-196.

Souza WM, Machado AM, Figueiredo LT, Boff E 2011. Serosurvey of hantavirus infection in humans in the border region between Brazil and Argentina. Rev Soc Bras Med Trop 44: 131-135.

Suzuki A, Bisordi I, Levis S, Garcia J, Pereira LE, Souza RP, Sugahara TK, Pini N, Enria D, Souza LT 2004. Identifying rodent hantavirus reservoirs, Brazil. Emerg Infect Dis 10: 2127-34.

Tanishita O, Takahashi Y, Okuno Y, Yamanishi K, Takahashi M 1984. Evaluation of focus reduction neutralization test with peroxidaseantiperoxidase staining technique for hemorrhagic fever with renal syndrome virus. J Clin Microbiol 20: 1213-1215.

Valdivieso F, Vial P, Ferres M, Ye C, Goade D, Cuiza A, Hjelle B 2006. Neutralizing antibodies in survivors of Sin Nombre and Andes hantavirus infection. Emerg Infect Dis 12: 166-168.

Vera-Otarola J, Solis L, Soto-Rifo R, Ricci EP, Pino K, Tischler ND, Ohlmann T, Darlix JL, Lopez-Lastra M 2012. The Andes hantavirus NSs protein is expressed from the viral small mRNA by a leaky scanning mechanism. J Virol 86: 2176-2187.

Yu L, Bai W, Wu X, Zhang L, Zhang L, Li P, Wang F, Liu Z, Zhang F, Xu Z 2013. A recombinant pseudotyped lentivirus expressing the envelope glycoprotein of hantaan virus induced protective immunity in mice. Virol J 10: 301 . 